УДК 338.48

\title{
ЭВОЛЮЦИЯ УСЛУГ ПРОМЫШЛЕННОГО ХАРАКТЕРА В РЕСПУБЛИКЕ БЕЛАРУСЬ В 1995-2015 ГГ.
}

\author{
Ю.В. МЕЛЕШКО \\ аспирант кафедры «Экономики и право» \\ Белорусского национального технического университета, г. Минск
}

\begin{abstract}
Аннотация
С иелью изучения развития услуг промышленного характера в Республике Беларусь в 1995-2015 г2. и выявления основных зависимостей между развитием промышленного комплекса и сферы услуг в статье был проведен статистический анализ изменения структуры ВВП Беларуси, структуры занятости, а также качественных $и$ количественных изменений, происходящих как в сфере производства, так и в сфере услуг за рассматриваемый период.

Ключевые слова: сфера услуг Республики Беларусь, сфера производства Республики Беларусь, промышленность Республики Беларусь, услуги промышленного характера.
\end{abstract}

Abstract

In order to study the development of industrial services in the Republic of Belarus in years 1995-2015 gg. and identify key relationships between the development of the Industrial sector and the service sector in the article was a statistical analysis of measurabletion structure of Belarus' GDP, employment structure, as well as the quality and co-quantitative changes occurring both in production and in services for the period under review.

Keywords: sphere Belarus service, the scope of production, the Republic of Belarus, Republic of Belarus, industry, industrial services.

\section{ВВЕДЕНИЕ}

При проведении анализа развития услуг промышленного характера в Республике Беларусь необходимо учитывать некоторые специфические особенности данной отрасли. В частности, услуги промышленного характера находятся на стыке двух сфер народного хозяйства производственной сферы, a именно промышленности и частично строительства, и сферы услуг. В зависимости от организационной формы оказания услуг промышленного характера один и тот же вид деятельности может быть статистически учтен и в промышленном производстве 
(в случае оказания этих услуг собственными структурными подразделениями предприятия), и в строительстве или в сфере услуг (в случае инсорсинга и аутсорсинга услуг промышленного характера).

Значительная часть услуг промышленного характера в Республике Беларусь оказывается в рамках предприятия своими структурными подразделениями. Для таких предприятий возникают дополнительные риски, связанные с необходимостью постоянного отслеживания состояния ранка непрофильного производства - рынка оказания услуг. Также требуется нести постоянные издержки по поддержанию необходимой компетенции персонала, оказывающего услуги промышленного характера (то есть занятого непрофильным производством), отвлекать часть работников вспомогательных служб для обслуживания этого же непрофильного производства (бухгалтерия, планово-экономический отдел, топ-менеджмент компании и т.д.). В результате, может возникнуть ситуация, когда оказание услуг промышленного характера собственными силами становится по существу планово-убыточным. Для того, чтобы этого избежать, необходимо осуществлять постоянный мониторинг потребности предприятия в услугах промышленного характера и изыскивать оптимальные организационные формы их оказания. Кроме того, оказания услуг промышленного характера предприятиями самостоятельно как дополнительная непрофильная деятельность зачастую связана с трудностями их учета и анализа, что может существенно затруднить повышение их экономической эффективности.

Анализ развития услуг промышленного характера, оказываемых сторонними организациями в рамках инсорсинга или аутсорсинга, также затруднен, поскольку статистические данные не в полной мере отражают субъектную и предметную специфику деятельности по оказанию услуг промышленного характера.

Учитывая сложность объекта и предмета нашего исследования, а также ограниченный институциональными рамками возможный объем этой работы, при проведении анализа услуг промышленного характера в Республике Беларусь более детально будем рассматривать период после 2005 г. Это обусловлено историческими особенностями развития белорусской экономики: с 1995 г. по 2005 г. - период десятилетнего восстановления, по результатом которого «Беларусь первой на постсоветском пространстве по основным параметрам достигла уровня докризисного 1990 г.» [1, с. 4]. С 2005 г. начался новый период - период «развития белорусской экономики» [1, с. 4], период «системной модернизации всех секторов экономики» [1, с. 4], длившийся до 2015 г. При этом автор оставляет за собой право в случае гносеологической и прагматической необходимости, обусловленной целью нашего 
исследования, раздвигать временные рамки проводимого анализа до 1990 г. Кроме того, при анализе эволюции услуг промышленного характера следует учитывать также и внешнеэкономические и политические факторы, а именно то, что «мир в XXI в. кардинально изменился. И дело не только в нарушении геополитических равновесий, формировании однополярного мира и усилении борьбы за все виды ресурсов, но и в том, что человечество начинает по-новому смотреть на цели и критерии общественного прогресса» [2, с. 74].

Поскольку зачастую при анализе статистических данных возникают проблемы их интерпретации, вызванные неверным пониманием исходных понятий, несовершенством используемых методик и неочевидностью отнесения тех или иных видов деятельности к сфере производства, в частности, промышленному производству, или же сфере услуг, при проведении статистического анализа, по нашему мнению, немаловажным является и понимание методик формирования статистических данных. В соответствии с пояснениями, приведенными в Методике по расчету общего объема промышленного производства и индексов промышленного производства, утвержденной Постановлением Национального статистического комитета Республики Беларусь от 13.11.2015 г. № 183, «промышленное производство охватывает горнодобывающую промышленность, обрабатывающую промышленность, снабжение электроэнергией, газом, паром, горячей водой и кондиционированным воздухом; водоснабжение; сбор, обработку и удаление отходов, деятельность по ликвидации загрязнений» [3]. К сельскохозяйственной деятельность относится деятельность по животноводству и растениеводству, а также рыболовство и рыбоводство. В соответствии с методическими пояснениями к статистическому сборнику «Сфера услуг в Республике Беларусь» [4], в объем услуг включается следующие виды экономической деятельности, относящиеся к секциям: «Торговля, ремонт автомобилей, бытовых изделий и предметов личного пользования», «Гостиницы и рестораны», «Транспорт и связь», «Финансовая деятельность», «Операции с недвижимым имуществом, аренда и предоставление услуг потребителям», «Образование», «Здравоохранение и предоставление социальных услуг», «Предоставление коммунальных, социальных и персональных услуг» [4]. Для статистических целей в отдельную категорию выделена секция «Строительство» и «Инвестиции».

Сегодня широкое распространение получило структурное разделение народного хозяйства на сферу производства и сферу услуг (по аналогии с разделением экономики в СССР на производственную и непроизводственную сферы). При такой типологии к сфере производства относится сельское и лесное хозяйство, рыболовство и рыбоводство; 
промышленность: горнодобывающая, обрабатывающая, производство и распределения электроэнергии, газа и воды; а также строительство. Оставшиеся виды деятельности относятся к сфере услуг. Кроме этого, в структуре валового внутреннего продукта выделяют такие сегменты, как сфера производства, сфера услуг, а также чистые налоги на продукты.

\section{РЕЗУЛЬТАТЫ И ИХ ОБСУЖДЕНИЕ}

В 1990-2015 гг. прослеживается устойчивая тенденция увеличения доли в структуре ВВП Республики Беларусь сферы услуг и уменьшение доли производственной сферы, сопровождаемая снижением доли сферы услуг с 44,55\% до $38,63 \%$ в 2000 г. и с 45,17\% до 43,66\% в 2012 г. После чего сфера услуг опять выходит на траекторию роста. Доля сферы производства в ВВП за рассматриваемый период снизилась на $27,4 \%$ (с 68,8\% в 1990 г. до 41,4\% в 2015 г.). При этом доля сферы услуг возросла с $28,6 \%$ в 1990 г. до $47,7 \%$ в 2015 г., то есть на $19,1 \%$ [5, с. 223; 6, с. 221]. Динамика доли сферы производства и сферы услуг в структуре ВВП за рассматриваемый период отображена на рисунке.

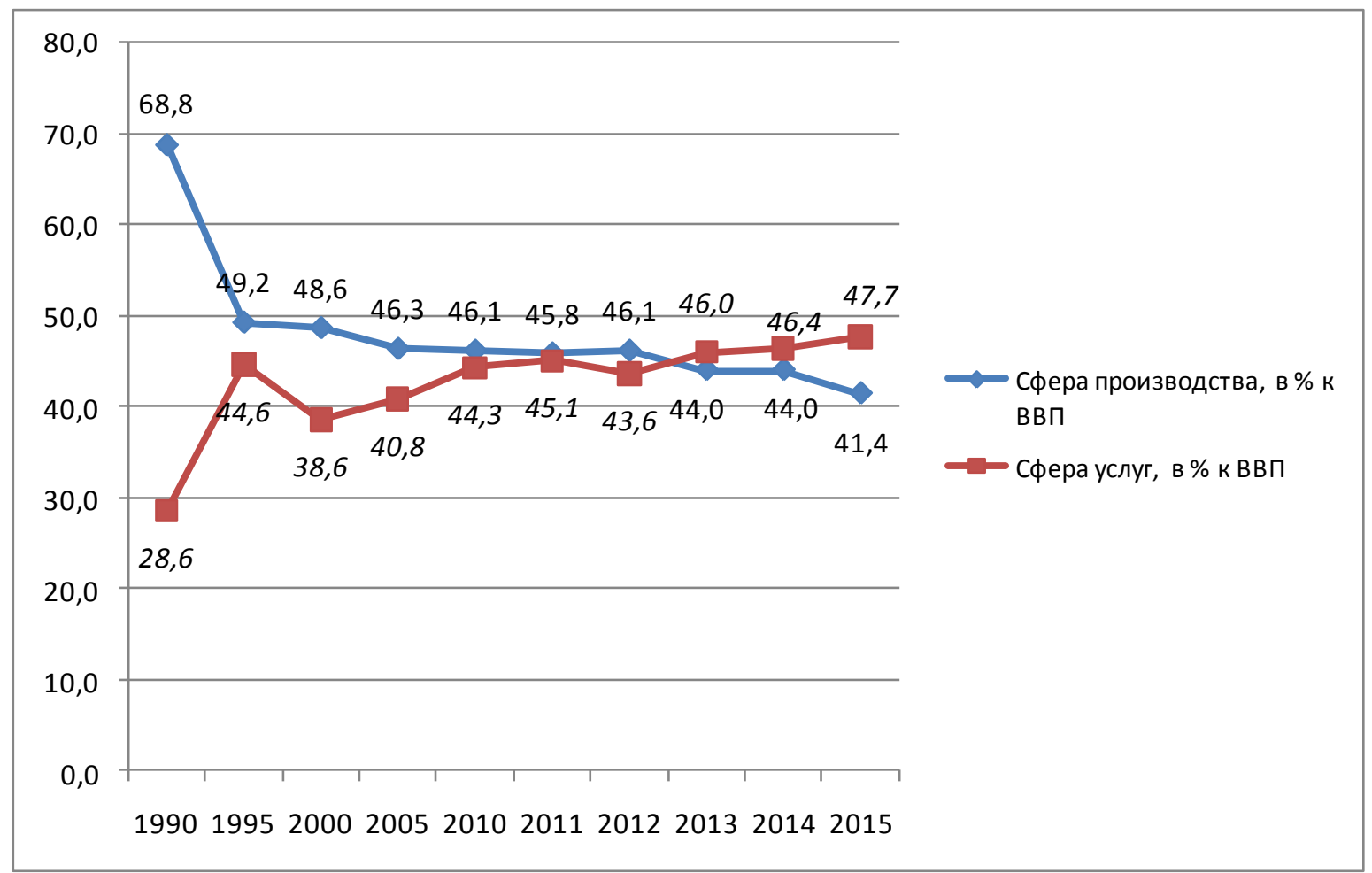

Динамика доли сферы производства и сферы услуг в структуре ВВП Республики Беларусь за период 1990-2015 гг. 
Изменение структуры ВВП нашей страны за счет опережающего развития сферы услуг, начавшегося с 2013 г., происходит на фоне снижения темпов роста ВВП Беларуси: если в 2005 г. темп роста ВВП составил 109,4\%, то в 2010 г. - 107,7\%, в 2011 г. - 105,5\%, 2012 г. $-101,7 \%, 2013$ г. $-101,0 \%, \quad$ в 2014 г. $-101,6 \%$, в 2015 г. - 96,1\% [5, с. 223; 6, с. 221]. Падение темпов роста ВВП Беларуси с 2010 г. явилось следствием мирового финансовоэкономического кризиса, геополитической нестабильности, что привело к снижению глобального совокупного спроса и сокращению экспорта белорусских товаров, отразившееся во всех секторах экономики. В таком контексте повышение доли сферы услуг в структуре ВВП свидетельствует о ее относительно высокой кризисоустойчивости.

Сфера услуг демонстрирует опережающий характер развития и по критерию занятости по видам экономической деятельности. Начиная с 1990 г. доля занятых в сфере производства постоянно снижалась и в 2015 г. достигла 40,8\%. За этот период доля занятых в сфере услуг увеличилась на $22,8 \%$ : с $36,4 \%$ в 1990 г. до $59,2 \%$ в 2015 г. [7, с. 106; 5, с.94; 6, с. 94]. Гораздо более высокий темп прироста занятых в сфере услуг по сравнению с темпом прироста сферы услуг в структуре ВВП Беларуси свидетельствует об относительно неэффективном развитии сферы услуг в части трудовых отношений.

Таким образом, следует отметить, что в контексте развития экономики Республики Беларусь за рассматриваемый период произошел количественный рост сферы услуг, выразившийся в увеличение доли сферы услуг в структуре ВВП с 28,64\% в 1990 г. до $47,7 \%$ в 2015 г. [5, с. $223 ; 6$, с. 221] и доли занятых в этой сфере с $36,4 \%$ в 1990 г. до 59,2\% в 2014 г. [7, с. 106; 5, с.94; 6, с. 94]. Однако само по себе этого не достаточно для выработки системного представления о структурных изменениях в экономике Республики Беларусь. Для решения задачи выявления корреляционных зависимостей между развитием сферы услуг и сферы производства следует рассмотреть изменения, происходящие в структурах этих сфер.

В сфере производства с 2000 по 2015 гг. наблюдается значительное снижение доли в структуре ВВП нашей страны сельского хозяйства (включая рыбоводство и рыболовство) - на 5,5\% (с 12,2\% в 2000 г. до $6,7 \%$ в 2015 г.), обрабатывающей промышленности - на 1,9\% (с 24,3\% в 2000 г. до 22,4\% в 2015 г.), производства и распределения электроэнергии, газа и воды - на 1,7\% (с 5\% в 2000 г. до 3,3\% в 2014 г.). Уменьшилась доля в структуре ВВП Беларуси также горнодобывающей промышленности, но в сравнении с другими отраслями производственной сферы незначительно: на $0,2 \%$ (с $0,9 \%$ до $0,7 \%$ ). Наибольшего значения доля обрабатывающей промышленности в структуре ВВП Республики Беларусь 
достигла в 2011 г. - 28,1\%, после чего произошел спад и в 2015 г. ее доля составила $22,4 \%$, что на 5,7\% меньше показателя 2011 г. [5, с. 240; 6, с. 241].

В 2000-2015 гг. белорусская промышленность претерпела значительные структурные изменения, происходящие на фоне периода активного роста белорусской экономики за счет «расширения масштабов производства» $[1$, с. 5] и «опережающего роста экспорта как на российский, так и на европейский рынок» [1, с.4] $(2000$ - 2009 гг.) и пришедшего на смену периода замедления роста (2011 - 2015 гг.), обусловленного в большей степени экзогенными факторами: мировой финансовый кризис в 2008-2009 гг., падение в 2013 г. уровня ВВП в Евросоюзе - «второго по значимости рынка для белорусского экспорта» [1, с.14], в 2014 г. - введение Европейским союзом санкций против России, геополитическая нестабильность в Украине. Начиная с 2011 г. наблюдалось сокращение товарооборота и снижение валютной выручки, чрезмерное увеличение запасов готовой продукции на складах белорусских производителей.

В структуре промышленного производства Республики Беларусь значительно возросла доля производства пищевых продуктов, включая напитки, и табака - на 4\% (с 19,7\% в 2000 г. до 23,7\% в 2015 г.). Положительная динамика наблюдалась также в сферах химического производства (рост доли в структуре промышленности на $2 \%$ : с 9,4\% в 2000 г. до $11,4 \%$ в 2014 г.), производства кокса, нефтепродуктов и ядерных материалов (рост доли в структуре промышленности (на 1,6\% : с 14,7\% в 2000 г. до 16,3\% в 2015 г.), металлургического производства и производства готовых металлических изделий (рост доли в структуре промышленности на 1,4\%: с 4,8\% в 2000 г. до 6,2\% в 2015 г.), производства резиновых и пластмассовых изделий (рост доли в структуре промышленности на 0,9\%: с 2,3\% в 2000 г. до 3,2\% в 2015 г.), производства прочих неметаллических минеральных продуктов (рост доли в структуре промышленности на $0,8 \%$ : с 3,5\% в 2000 г. до 4,3\% в 2015 г.), обработки древесины и производства изделий из дерева (рост доли в структуре промышленности на 0,4\%: с 1,7\% в 2000 г. до 2,1\% в 2015 г.), а также горнодобывающей промышленности (рост доли в структуре промышленности на $0,1 \%$ : с 1,3\% в 2000 г. до 1,4\% в 2015 г.). При этом значительно сократились доля в структуре промышленности текстильного и швейного производства (на 4,2\%: с 7\% в 2000 г. до $2,8 \%$ в 2015 г.), доля в структуре промышленности производства и распределения электроэнергии, газа и воды (на 2,2\%: с 12,7\% в 2000 г. до 10,2\% в 2015 г.), производства машин и оборудования (на 2,2\%: с 8,9\% в 2000 г. до 6,7\% в 2015 г.). Также сократилась доля в структуре промышленности 
сферы производства транспортных средств и оборудования (на 1,5\%: с 4,5\% в 2000 г. до $3 \%$ в 2015 г.) [5, с. 276 ; 6, с. 278,7 , с. 293].

Исходя из приведенного выше анализа структуры объема промышленного производства по видам экономической деятельности видно, что структура промышленного производства Республики Беларусь за период с 2000 г. до 2015 г. изменилась в сторону увеличения доли материалоемких и в большинстве случаев неблагоприятных для экологии производств. В частности, в 2015 г. количество выбросов загрязняющих веществ в атмосферный воздух организациями в сфере производство кокса, нефтепродуктов и ядерных материалов составило 90,4 тысяч тонн, что в процентном соотношении к общему объему выбросов загрязняющих веществ в атмосферу предприятиями промышленности составило 35,5\%. Для организаций в сфере производства прочих неметаллических минеральных продуктов данный показатель достиг 24,4 тысяч тонн, что составило 9,6\%. Предприятиями по производству пищевых продуктов, включая напитки, и табака в атмосферный воздух было выброшено 17,3 тысяч тонн загрязняющих веществ, что составило $6,8 \%$, предприятиями химической промышленности - 14,4 тысяч тонн, что составляет 5,7\% [5, с. 64-67; 6, с. 56-60]. Использование экологических ресурсов позволило повысить уровень конкурентоспособности отечественной продукции на международном рынке, вместе с тем такой подход может иметь крайне негативные последствия для будущего поколения.

Производство кокса, нефтепродуктов и ядерных материалов является на сегодняшний день наиболее материалоемким производством в сфере промышленности: в 2015 г. доля материальных затрат в структуре затрат на производство продукции (работ, услуг) составила 93,6\%. Также к отраслям, чья продукция обладает высокой степенью материалоемкости, относятся производство пищевых продуктов, включая напитки, и табака (82,3\%), металлургического производства и производства готовых металлических изделий (80,3\%), производства резиновых и пластмассовых изделий $(74,1 \%)$, химическое производство $(71,3 \%) \quad[6, \quad$ c. 285]. Для указанных производств высокая степень материалоемкости производимой продукции является объективно обусловленным фактором и при сохранении качества производимой продукции неизбежным, вместе с тем по мере внедрения данными предприятиями технологических и иных инноваций и увеличения доли выпуска инновационной продукции, уровень материалоемкости будет сокращаться вследствие увеличения затрат на оплату труда и амортизацию основных средств и нематериальных активов.

По уровню рентабельности продаж лидером среди отраслей белорусского промышленного комплекса в 2015 г. являлось химическое 
производство - 21,6\%, при этом начиная с 2009 г. эта отрасль в среднем показывала наиболее высокие показатели уровня рентабельности. Выше среднего уровня рентабельности продаж промышленных товаров, который в 2015 г. составил 8,7\%, показывают такие отрасли промышленности, как горнодобывающая промышленность $(9,3 \%)$, текстильное и швейной производство $(9,6 \%)$, производство кожи, изделий из кожи и производство обуви $(14,9 \%)$, производство машин и оборудования $(10,2 \%)$, производство электрооборудования, электронного и оптического оборудования $(8,8 \%)$. В натуральном выражении наибольшую прибыль среди отраслей промышленности в 2015 г. принесли химическое производство (20 018 млрд. руб.), производство пищевых продуктов, включая напитки, и табака (14 193 млрд. руб.), производство и распределение электроэнергии, газа и воды (9 305 млрд. руб.), производство кокса, нефтепродуктов и ядерных материалов (7 328 млрд. руб.) [5, с. 275 , с. 289 - 301, с. 290 , С.303-305; 6, с. 277 , c. 291-303, с. 305-307].

Положительная динамика развития ряда отраслей белорусской промышленности во многом предопределена проводимой инвестиционной политикой, направленной на технико-технологическое перевооружение и модернизацию действующих предприятий реального сектора экономики. С 2000 г. по 2010 г. объем инвестиций в основной капитал организаций обрабатывающей промышленности постоянно снижался, так, если в 2000 г. инвестиций в основной капитал организаций обрабатывающей промышленности составляли $23,7 \%$ от общего объема инвестиций, то в 2010 г. этот показатель снизился до 19,4\%. В 2011 г. доля инвестиций в основной капитал организаций обрабатывающей промышленность Республики Беларусь достигла рекордно высоких показателей - 28,6\%, и после некоторого спада в 2011 г. и 2012 г., когда доля инвестиций составляла соответственно $26,7 \%$ и $23,6 \%$, вновь возросла и составила в 2014 г. 27,3\%. В 2015 г. вновь произошел рост инвестиций в сельское хозяйство до $10,9 \%$ и сокращение притока инвестиций в основной капитал предприятий обрабатывающей промышленности до $26,8 \%$ [5, с. $438 ; 6$, с. 432-433].

Наибольшее количество инвестиций в основной капитал среди отраслей обрабатывающей промышленности было направлено в химическое производство. Их доля от общего объема инвестиций в основной капитал составила в 2000 г. $-5,6 \%$, в 2005 г. $-6,0 \%$, 2008 г. - 4,7\%, 2009 г. - 4,1\%, 2010 г. - 3,8, 2011 г. - 5,7\%. С 2012 г. объем инвестиций в химическую отрасль начал сокращаться и составил в 2014 г. $2,7 \%$, однако в 2015 г. вновь увеличился до 4,7\% [5, с. 438; 6, с. 432-433]. Повышенный интерес к химической отрасли обусловлен, как справедливо 
было отмечено Э. И. Петровичем, стратегией «комплексной химизации отраслей экономики как необходимое условие повышение эффективности производства и ускорения научно-технического процесса» [8].

В 2000-2015 гг. предприятия пищевой промышленности получали на постоянной основе довольно большие объемы инвестиций в основной капитал: минимальная доля инвестиций в основной капитал этой отрасли составила 3,4\% к итогу в 2000 г., максимальная - 4,9\% в 2011 г. В 2015 г. доля инвестиций в основной капитал в сфере производства пищевых продуктов, включая напитки, и табака составила $4,8 \%$ [5, с. $438 ; 6$, с. 432-433]. Постоянный приток инвестиций на достаточно высоком уровне в этой сфере объясняется тесной связью с сельским хозяйством и реализацией политики продовольственной безопасности Республики Беларусь.

Еще одной отраслью, для которой характерен относительно стабильный приток инвестиций, хотя и в меньших объемах, чем в пищевую промышленность, является производство кокса, нефтепродуктов и ядерных материалов. Доля инвестиций в основной капитал организаций этой отрасли колебалась от $1,8 \%$ от общего объема инвестиций (в 2000 г. и 2010 г.), до 3,8\% в 2015 г. [5, с. 438; 6, с. 432-433]. Постоянный приток инвестиций в этой сфере предопределен необходимостью поддержки высокого уровня инновационности производства. Так, производство кокса, нефтепродуктов и ядерных материалов является лидером среди отраслей промышленности по объему отгруженной инновационной продукции: в 2015 г. объем объему отгруженной инновационной продукции составил $38,1 \%$ от общего объема отгруженной продукции [5, с. $389 ; 6$, с. 391$]$.

Начиная с 2009 г. увеличились инвестиции в производство прочих неметаллических минеральных продуктов (2008 г. - 2,8\%, 2009 г. - 3,7\%, 2010 г. $-3,1 \%, 2011$ г. - 6,3\%), что было связано с ростом потребностей в продукции строительного комплекса. Однако после 2013 г. объем инвестиций в данную отрасль резко сократился и их доля в 2015 г. составила лишь $0,9 \%$ от общего объема инвестиций в основной капитал $[5$, с. $438 ; 6$, с. $432-433]$.

В сфере производства единственной отраслью, показывающей положительную динамику изменения доли в структуре ВВП Республики Беларусь в 2000-2015 гг., являлось строительство. В 2000 г. доля строительства в структуре ВВП составляла 6,3\% и увеличилась к 2014 г. на 4,1\% (до 10,5\%). После этого, однако, в 2015 г. произошло сокращение доли строительства в структуре ВВП Беларуси до 8,3\% [5, с. 240; 6, с. 241]. Такое существенное увеличение доли строительства в структуре ВВП нашей страны обусловлено в том числе (помимо гражданского строительства) и за счет широкомасштабного строительства производственных мощностей, 
непосредственно связанных с модернизацией и развитием предприятий сельского хозяйства и обрабатывающей промышленности (в первую очередь предприятий в сфере животноводства, растениеводства и пищевой промышленности, а также химического производства и производства нефтепродуктов) [5, с. 333].

С 2000 по 2015 г. происходили структурные изменения и в сфере услуг. Традиционным лидером среди видов деятельности, относящихся к сфере услуг, по показателю доли в структуре ВВП Республики Беларусь является секция «Торговля, ремонт автомобилей, бытовых изделий и предметов личного пользования». Ее доля в структуре ВВП Беларуси с 2000 г. по 2011 г. выросла с 10,2\% до 15,3\%, после чего наблюдался некоторый спад, и в 2015 г. данный показатель составил 12,5\% [5, с. 240; 6, с. 241]. По показателю доли в ВДС сферы услуг торговля и ремонт занимает с 2009 г. неизменно первое место: начиная с 2009 г., когда данный показатель составил $28,3 \%$, доля в ВДС сферы услуг рассматриваемой секции постоянно возрастала и достигла в 2012 г. показателя в 33,7\%. В 2013 г. и 2014 г. наблюдалось уменьшение в ВДС сферы услуг доли торговли и ремонта до $27,4 \%$ и $26,7 \%$ [4, с. $29 ; 14$, с.8; 15, с. $8 ; 16$, с.8].

Внутри секции «Торговля, ремонт автомобилей, бытовых изделий и предметов личного пользования» лидером является оптовая торговля и торговля через агентов: в 2015 г. ее доля в выручке от реализации продукции, работ, услуг организаций с основным видом экономической деятельности «Торговля; ремонт автомобилей, бытовых изделий и предметов личного пользования» составила $56,6 \%$ [5, с. $358 ; 6$, с. 359]. В соответствии с методологическими пояснениями к статистическому сборнику «Розничная и оптовая торговля, общественное питание в Республике Беларусь» [13] оптовый товарооборот представляет собой «стоимость товара (продукции) несобственного производства, фактически отгруженных без их видоизменения сторонним организациям и индивидуальным предпринимателям, с целью их дальнейшей перепродажи или для собственного использования (переработки)» [13, с. 12] . Следовательно, при оценке объемов торговли в Республике Беларусь следует учитывать, что статистически в группе оптовой торговли, которая занимает наибольшую долю внутри секции «Торговля; ремонт автомобилей, бытовых изделий и предметов личного пользования», также учитывается деятельность по торговле средствами производства, материалами и комплектующими для всех иных сфер производства, в том числе и промышленности.

Углубление технологической специализации производства как на международном, так и на национальном уровне способствуют активизации кооперационных связей, в том числе и в форме торговых 
отношений. Кроме того, более $1 / 5$ основной цены белорусской продукции и услуг составляет импорт. В производственной сфере наиболее импортоемкими являются производство транспортных средств и оборудования, производство электрооборудования, электронного и оптического оборудования и производство машин и оборудования, которые в соответствии с методологическими рекомендациями Евростата и ОЭСР относятся к высокотехнологичным и среднетехнологичным (высокого уровня) отраслям [17] . Доля импорта в продукции этих отрасли (в основных ценах) в 2014 г. составила 57,5\%, 56,3\% и 43,28\%, соответственно. Для ряда активно развивающиеся в Республике Беларусь отраслей обрабатывающей промышленности также характерно высокая импортоемкость продукции: для металлургического производства и производства готовых металлических изделий данный показатель составил в 2014 г. 46,16\%, для химического производства - 38,47\%, для производство резиновых и пластмассовых изделий $-33,62 \%$ [18, с. 47]. Таким образом, учитывая углубляющуюся специализацию производства и степень импортоемкости продукции белорусских производителей, такие высокие показатели доли торговли в ВВП Республики Беларусь и доли торговли в ВДС сферы услуг представляется оправданными.

Транспорт и связь в Республике Беларусь также традиционно занимают высокую долю в структуре ВВП: в 2000 г. этот показатель составил $9 \%$. Однако начиная с 2000 г. с некоторыми колебаниями в сторону роста в 2009 г. и 2013 г. доля в структуре ВВП Беларуси секции «Транспорт и связь» падала и в 2015 г. достигал показателя в 7,7\% [5, с. 240; 6, с. 241]. Несмотря на падение доли транспорта и связи в целом в структуре ВВП Беларуси, среди иных отраслей сферы услуг данная отрасль имеет достаточно большую долю в ВДС сферы услуг: в 2014 г. она достигла 17,5\%, что, однако, на $1,4 \%$ ниже, чем в 2009 г. [4, с. $29 ; 14$, с.8; 15, с.8; 16, с.8]. Секция «Транспорт и связь» в 2000-2015 гг. имела стабильный приток инвестиций на высоком уровне: минимальное количество инвестиций в размере $8,9 \%$ от общего количества инвестиций в основной капитал эта секция получала в 2009 г., максимальное - в 15\% в 2005 г. В 2015 г. доля инвестиций, полученных транспортом и связью, составила $10,7 \%[5$, с. $438 ; 6$, с. $432-433]$.

Следует отметить, что транспортные услуги являются основной статьей в экспорте услуг: в 2015 г. их доля в экспорте услуг составила 44,0\% [5, с. 499; 6, с. 495-496]. Кроме того, экспортные показатели в натуральном выражении (млн. долл. США) транспортных услуг начиная с 2005 г., за исключением небольшого спада в 2014 г. и 2015 г., постоянно росли: в 2005 г. транспортные услуги были экспортированы на сумму 1341,2 млн долл. США, в 2013 г. доход 
от экспорта транспортных услуг увеличился почти втрое и составил 3 792,4 млн. долл. США, в 2014 г. - 3 720,9 млн. долл. США, в 2015 г. - 2 928,0 млн. долл. США [5, с. 499; 6, с. 495-496].

В 2014 г. наибольшую долю в структуре ВВП нашей страны среди отраслей сферы услуг после торговли и ремонта впервые заняла секция «Операции с недвижимым имуществом, аренда и предоставление услуг потребителем». Начиная с 2000 г. доля этой отрасли в структуре ВВП постоянно увеличивалась, небольшой спад на 0,1-0,2\% наблюдался лишь в 2011 г. и 2012 г. С 2000 г. по 2015 г. доля в структуре ВВП Республики Беларусь операций с недвижимым имуществом, аренда и предоставление услуг потребителем увеличилась на 5,2\%: с 4,1\% до 9,3\%, что составляет наибольший темп роста доли в структуре ВВП Беларуси среди иных отраслей сферы услуг. Для сравнения, за рассматриваемый период доля торговли в структуре ВВП Беларуси увеличилась на 2,3\%, а финансовой деятельности - на 1,7\% [5, с. 240; 6, с. 241].

Секция «Операции с недвижимым имуществом, аренда и предоставление услуг потребителем» является весьма неоднородной и включает в себя такие виды деятельности, как, непосредственно, операции с недвижимым имуществом и аренда машин и оборудования без оператора и прокат бытовых изделий и предметов личного пользования, а также деятельность, связанная с вычислительной техникой, научные исследования и разработки и предоставление прочих видов услуг потребителям. Следует отметить, что именно в эту группу будут статистически учитываться большая часть услуг промышленного характера, в том числе научно-исследовательскую деятельность, инжиниринг, юридические, бухгалтерские услуги и т.д. (за исключением торговли и транспортных услуг), оказываемых в рамках инсорсинга или аутсорсинга.

В секции «Операции с недвижимым имуществом, аренда и предоставление услуг потребителем» наиболышую часть занимают операции с недвижимым имуществом: в 2014 г. объем оказания данных услуг составил 21879,2 млрд. руб., что составило 7,2 \% от общего объема оказанных услуг в этом году $[4$, с. $59 ; 14$, с. $14 ; 15$, с. $12 ; 16$, с. 12]. Высокая доля операций с недвижимым имуществом в общем объеме оказываемых услуг связано со значительным ростом объемов промышленного и гражданского строительства, начавшегося с 2013 г. [5, с. 240; 6, с. 241].

Высокие темпы роста объемов оказываемых услуг демонстрирует деятельность, связанная с вычислительной техникой. Ее доля в объеме оказываемых услуг начиная с 2009 г. стабильно растет: в 2009 г. этот показатель составил $1,92 \%$, что в натуральном выражении равнялось 1 038,4 млрд. руб., в 2010 г. - 2,14\% (1 402,6 млрд руб.), 
в 2011 г. - 2,48\% (3 193,7 млрд руб.), в 2012 г. - 3\% (6 306,2 млрд руб.), в 2013 г. - 3,4\% (8 779,1 млрд руб.), в 2014 г. $-3,9$ (11 852,8 млрд руб.) [4, с. $59 ; 14$, с. $14 ; 15$, с. $12 ; 16$, с. 12]. При этом телекоммуникационные, компьютерные и информационные услуги занимают в структуре экспорта услуг второе место после транспортных услуг: с 2005 г. по 2015 г. выручка от экспорта этих услуг ежегодно возрастает и в сумме за указанный период составила 4 836,9 млн. долл. США [5, с. 499; 6, с. 495-496]. Часть услуг, связанных с вычислительной техникой, также являются услугами промышленного характера и по мере модернизации белорусской промышленности в сторону технологического усложнения их доля будет возрастать.

Более $1 / 3$ в секции «Операции с недвижимым имуществом, аренда и предоставление услуг потребителем» занимает группа «Предоставление прочих видов услуг потребителям». При этом следует отметить, что, внушительную их долю в общем объеме оказываемых услуг (в 2014 г. доля прочих видов услуг в общем объеме оказываемых услуг составила $6,5 \%$, для сравнения доля образования в общем объеме оказываемых услуг составила $0,2 \%)$ [4, с. $59 ; 14$, с. $14 ; 15$, с. $12 ; 16$, с. 12], данная группа не расшифрована более подробно, что свидетельствует о ее высокой степени дифференцированности.

Секция «Операции с недвижимым имуществом, аренда и предоставление услуг потребителем» является лидером среди сферы услуг по количеству получаемых в 2000-2015 гг. инвестиций. Более того, объем получаемых инвестиций отраслями данного сектора сопоставим с объемом инвестиций, получаемых всеми отраслями обрабатывающей промышленности: в 2000 г. этой секцией было получено $28,8 \%$ от всего объема инвестиций в основной капитал, в 2015 г. $-26,1 \%$ [ 5 , с. $438 ; 6$, с. $432-433]$.

С 2009 г. по 2014 г. наблюдалась отрицательная динамика объемов оказания услуг в области научных исследований и разработок. Если в 2009 г. их доля в общем объеме оказываемых услуг составляла 1,68\% (в натуральном выражении в 2009 г. объем оказанных услуг в области научных исследований и разработок составил 909,5 млрд руб.), то в 2014 г. этот показатель снизился до $0,9 \%$ (в натуральном выражении - 2789,2 млрд руб.) [4, с. 59; 14, с. 14; 15, с. 12; 16, с. 12].

Сокращение объемов научных исследований и разработок, падение научно-исследовательской активности коммерческих организаций в 2013 г. и 2014 г. не могло не сказаться на количестве патентов, полученных национальными заявителями. В 2013 г. национальными заявителями было подано 1489 заявок, в 2014 г. более чем вдвое меньше - 652, в 2015 г. - 543. Количество полученных национальными 
заявителями патентов в 2013 г. составило 1027, а в 2014 г. - 887, в 2015 г. - 803 (превышение количества полученных патентов по отношению к поданным заявкам объясняется получением патентов в 2014 г. по заявкам, поданным ранее в виду длительности процедуры патентной экспертизы). Для сравнения, в 2010 г. национальными заявителями было подано 1759 заявок, выдано патентов - 1126 [5, с. $385 ; 6$, с. 384$]$.

В период с 2000 г. по 2015 г. доля финансовой деятельности в структуре ВВП Республики Беларусь возросла на 1,7\%: с 2,6 до 4,3\%. При этом в 2011 г. значение данного показателя составляло 4,8\%, после чего в 2012 г. снизилось до 3,7\%, а в 2013 г. - до 3,6\% [5, с. 240; 6, с. 241].

Примечательным является то, что пиковое значение доли в структуре ВВП обрабатывающей промышленности в 2011 г. соответствует также максимальному значению данного показателя и для сферы торговли $(15,3 \%)$ и финансовой деятельности $(4,8 \%)$ [5, с. 240; 6, с. 241]. За последующие 3 года доля в структуре ВВП этих секторов так же, как и обрабатывающей промышленности, сократилась. Такая динамика обрабатывающей промышленности и финансовой сферы, а также высокие показатели финансовой сферы в 2011 г. на фоне мирового финансового кризиса свидетельствует об имеющейся тесной взаимосвязи между ними при доминировании сферы производства. Иными словами, развитие финансовой сферы происходит не само по себе (развитие «фиктивных» финансов), а в соответствии с развитием реального сектора экономики, в частности обрабатывающей промышленности, где финансы выступают в качестве необходимых оборотных средств. Аналогичным образом связаны промышленное производство и торговля, существенную часть которой составляет деятельность по обеспечению предприятий промышленности материалами и комплектующими, а также средствами производства.

Учитывая функциональное назначение услуг промышленного характера, а именно удовлетворение потребностей предприятий промышленного комплекса, повышение конкурентоспособности промышленной продукции путем совершенствования производственного процесса на протяжении всей цепочки создания стоимости, инновационная деятельность предприятий промышленности, как то, например, исследование разработка новых продуктов, приобретение новых и высоких технологий или высокотехнологичного оборудования, является, по существу, услугами промышленного характера. Стоит отметить, что область услуг промышленного характера гораздо шире по сравнению с инновационной деятельностью предприятия, но при этом справедливо утверждение, что такая деятельность всегда представляет собой услуги промышленного характера. В связи с этим в рамках нашего исследования 
представляет особый интерес анализ инновационной активности предприятий промышленного комплекса.

С 2010 г. по 2012 г. уровень инновационной активности организаций промышленности значительно вырос (с 18,1\% до 24,8\%), однако с 2013 г. наблюдалась отрицательная динамика: в 2013 г. данный показатель составил $24,4 \%$, в 2014 г. - 22,8\%, в 2015 г. - 21,1\% [19, с. 13]. Сегодня инновационная активность абсолютного большинства предприятий промышленного комплекса заключается в использовании технологических инноваций, то есть «внедрении новой продукции или услуги, являющихся новыми или значительно улучшенными по части их свойств или способов использования» (продуктовая инновация) или «внедрении нового или значительно улучшенного способа производства (оказания услуги)» (процессная инновация) [19, с. 77]. В 2015 г. 92,7\% организаций промышленности, осуществивших затраты на инновационную деятельность, использовали технологические инновации [19, с. 84].

Начиная с 2005 г. существенно сократилась доля организаций промышленности, осуществляющих технологические инновации посредствам самостоятельного исследования и разработки продуктов, услуг и методов их производства (передачи), новых производственных процессов: если в 2005 г. их доля в общем количества предприятий промышленности, внедряющих технологические инновации, составляла $48,1 \%$, в 2010 г. - 58,9\%, то в 2015 г. - только 35,6\%. Основным способом внедрения технологических инноваций начиная с 2005 г. являлось приобретение машин и оборудования. При этом, однако, доля предприятий, приобретающих машин, оборудования, связанных с технологическими инновациями, также сократилась: в 2005 г. доля таких предприятий в общем количестве предприятий промышленности, внедряющих технологические инновации, составляла $71,3 \%$, в 2015 г. $-44,1 \%$ [19, с. $81 ; 20$, с. 78$]$.

Следует также учитывать разность затрат на проведение различных видов технологических инноваций. В 2015 г. 54,9\% всех затрат на технологические инновации были потрачены на приобретение машин и оборудования, 37,8\% - на производственное проектирование, 6,7\% - на исследования и разработки, и по 0,1\% на приобретение новых и высоких технологий, приобретение компьютерных программ и баз данных, подготовку, переподготовку и повышение квалификации персонала, маркетинговые исследования [6, с. 384].

Доля инновационно-активных предприятий, внедряющих организационные инновации, которые представляют собой «внедрение нового организационного метода в деловой практике организации, в организации рабочих мест или внешних связях» [19, с. 77], составила 
в 2015 г. 11,7\%. При этом наиболее активно в 2015 г. организационные инновации используют предприятия в области обработки древесины и производство изделий из дерева (50\%), производства кокса, нефтепродуктов и ядерных материалов $(33,3 \%)$, горнодобывающей промышленности $(25 \%)$, производство прочих неметаллических минеральных продуктов $(21,1 \%)$, химическое производство $(17,9 \%)[19$, с. 84$]$.

Доля инновационно-активных предприятий промышленного комплекса, внедряющих маркетинговые инновации, в 2015 г. составило $16,5 \%$. Под маркетинговыми инновациями понимают «внедрение нового метода маркетинга, включая значительные изменения в дизайне или упаковке продукта, продвижении на рынок или использовании новых стратегий ценообразования» $[19$, с. 77]. Наиболее активно маркетинговые инновации в 2015 г. использовали предприятия в сфере производства кожи, изделий из кожи и производство обуви $(44,4 \%)$, производства пищевых продуктов, включая напитки, и табака $(25,9 \%)$, горнодобывающая промышленность $(25,0 \%)$, целлюлозно-бумажное производство, издательская деятельность $(25,0 \%)$ [19, с. 84$]$.

\section{ВЫВОДЫ}

Проведенное исследование макроэкономической ситуации в Республике Беларусь с 1995 по 2015 г. в контексте исследования услуг промышленного характера позволило выявить основные структурные сдвиги, произошедшие как на уровне изменения соотношения производственного сектора и сектора услуг, так и внутри указанных секторов. В частности, установлено, что за рассматриваемый период увеличилась доля сектора услуг как в структуре ВВП Республики Беларусь, так и в занятости. В производственной сфере с 1995 г. по 2015 г. произошло сокращение доли в структуре ВВП сельского хозяйства, промышленного производства, как добывающего, так и обрабатывающего, производства и распределение электроэнергии, газа и вода, рост был характерен лишь для строительства, при этом значительный. Среди отраслей обрабатывающей промышленности наибольшее развитие получили производство пищевых продуктов, включая напитки, и табака, химическое производство, производство кокса, нефтепродуктов и ядерных материалов, металлургическое производство и производство готовых металлических изделий, производство резиновых и пластмассовых изделий, производство прочих неметаллических минеральных продуктов.

С 1995 г. по 2015 г. в секторе услуг доминирующее положение занимала торговля и ремонт. Транспорт и связь, находящиеся традиционно 
на втором месте, в 2014 г. уступили секции «Операции с недвижимым имуществом, аренда и предоставление услуг потребителям». При этом последняя, имея наибольшие темпы прироста в структуре ВВП среди отраслей сферы услуг и наибольшее количество инвестиций среди всех отраслей народного хозяйства Республики Беларусь, аккумулирует в себе основную часть услуг промышленного характера (кроме оптовой торговли, транспорта и связи), оказываемых в рамках инсорсинга или аутсорсинга.

На основании проведенного анализа была выявлена зависимость между развитием отраслей промышленности и таких отраслей сферы услуг, как торговля, транспорт и финансовая деятельность. Кроме того, установлено, что инновационная активность предприятий промышленного комплекса напрямую зависит от использования услуг промышленного характера, при помощи которых решается задача повышения конкурентоспособности промышленной продукции путем совершенствования производственного процесса на всей цепочке создания стоимости.

\section{ЛИТЕРАТУРА}

1. Из доклада Президента Республики Беларусь А. Г. Лукашенко на пятом всебелорусском народном собрании // Беларуская думка. - 2016. №7. - C.4-21.

2. Солодовников, С. Ю. Гносеологические трудности при изучении классов в постиндустриальном обществе С. Ю. Солодовников //Социальный альманах. - 2012. - №3. - С.74-91.

3. Методика по расчету общего объема промышленного производства и индексов промышленного производства: Постановление Национального статистического комитета Республики Беларусь от 13.11.2015 г. № 183 [Электронный ресурс] // Национальный статистический комитет Республики Беларусь. - Режим доступа: http://www.belstat.gov.by/metodologiya/metodiki-po-formirovaniyu-i-raschetustatistichesk/. - Дата доступа: 10.08.2016.

4. Сфера услуг в Республике Беларусь: статистический сборник. Минск, 2012. - 303 с.

5. Статистический ежегодник Республики Беларусь, 2015. Минск, 2015. - 525 с.

6. Статистический ежегодник Республики Беларусь, 2016. Минск, 2016. - 519 с.

7. Статистический ежегодник Республики Беларусь, 2000. Минск, 2000. - 583 с. 
8. Петрович, Э. И. Инвестиционная политика и социальноэкономическое развитие Беларуси в 2001-2015 гг. / Э. И. Петрович // Экономический бюллетень НИЭИ Министерства экономики Республики Беларусь. - 2016. - №6. - C.4-13.Розничная и оптовая торговля, общественное питание в Республике Беларусь: статистический сборник. Минск, 2015. - 228 с.

10. Сфера услуг в Республике Беларусь за 2012 год. - Минск, 2013. $-51 \mathrm{c}$.

11. Сфера услуг в Республике Беларусь за 2013 год. - Минск, 2014. -49 c.

12. Сфера услуг в Республике Беларусь за 2014 год. - Минск, 2015. $-47 \mathrm{c}$.

13. Система показателей Республики Беларусь для статистической оценки уровня технологического развития отраслей экономики: методики по формированию и расчету статистических показателей [Электронный pecypc] // Национальный статистический комитет Республики Беларусь. Режим доступа: http://www.belstat.gov.by/metodologiya/metodiki-poformirovaniyu-i-raschetu-statistichesk/ - Дата доступа: 13.09.2016.

14. Система таблиц «Затраты-выпуск» Республики Беларусь за 2014 г.: статистический бюллетень. - Минск, 2016. - 105 с.

15. Наука и инновационная деятельность в Республике Беларусь: статистический сборник. - Минск, 2016. - 142 с.

16. Наука и инновационная деятельность в Республике Беларусь: статистический сборник. - Минск, 2015. -137 с.

Статья поступила в редакиию 30 ноября 2016 года. 